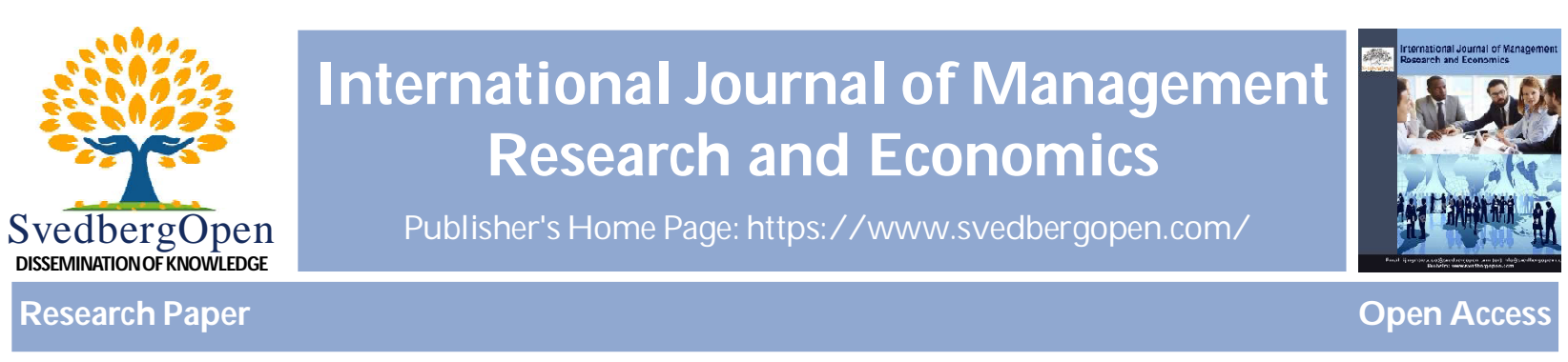

\title{
The Invention of Double-Entry Bookkeeping
}

\author{
Maxime Izoulet $^{1^{*}}$ \\ ${ }^{1}$ Doctor of Economics, Researcher at CEMI-CRS, Paris, Accounting Officer at Lycée Théodore de Banville, Moulins, France. \\ E-mail: maxime.izoulet@gmail.com
}

\section{Article Info}

Volume 1, Issue 4, October 2021

Received : 12 January 2021

Accepted : 28 August 2021

Published : 05 October 2021

doi: 10.51483/IJMRE.1.4.2021.48-60

\begin{abstract}
Based on the work of Jean Fourastié, accountant and economist, this paper seeks to show that the origins of double-entry bookkeeping are the result of several successive innovations that appeared in Italian commercial enterprises between the $13^{\text {th }}$ and $14^{\text {th }}$ centuries in response to the development of credit and receivables. The three successful innovations that led to the invention of double-entry bookkeeping are thus analyzed in detail from an accounting and logical point of view. This invention, which will have considerable consequences for the emergence of our modern monetary and banking systems, leads to a precise and efficient definition of value, which we still depend on today, especially to understand financial crises.
\end{abstract}

Keywords: Accounting, Finance, Credit, Debit, Banking, History

(C) 2021 Maxime Izoulet. This is an open access article under the CC BY license (https://creativecommons.org/licenses/by/4.0/), which permits unrestricted use, distribution, and reproduction in any medium, provided you give appropriate credit to the original author(s) and the source, provide a link to the Creative Commons license, and indicate if changes were made.

\section{Introduction}

As this paper asserts, it was double-entry bookkeeping that allowed the emergence of credit money from the Middle Ages onwards. It is therefore necessary to define this technique. But defining double-entry bookkeeping is not as simple as one might think, and accounting thought has often failed to do so clearly. Indeed, the question of defining the value underlying double-entry accounting is often avoided, even though it is its most important contribution. In fact, only Jean Fourastié, who before becoming an economist was an accountant for a long time, succeeded in 1943 in giving a clear and logical definition of this technique, following research into its historical origins. To understand this, in fact, is to explain the way in which the double entry was progressively constituted, and in response to what constraints. The counter-intuitive and tangled aspect of the double part is then illuminated, and one can rationally reflect on its function and definition from this knowledge. It is extremely regrettable that Jean Fourastié's method of accounting analysis has not been more widely used, even though its practical and theoretical effectiveness was widely recognized until the early 2000s and led to the establishment of many effective institutions, starting with the French General Accounting Plan, which is still used today by all companies and administrations. We will see in a specific section the contextual reasons that can be given for this weakening of accounting thought, which are not unrelated to the evolution of contemporary finance.

\footnotetext{
* Corresponding author: Maxime Izoulet, Doctor of Economics, Researcher at CEMI-CRS, Paris, Accounting Officer at Lycée Théodore de Banville, Moulins, France. E-mail: maxime.izoulet@gmail.com
} 
On the contrary, this article takes this historical analysis, this genealogy, as its starting point, and tries to push it even further, by showing that the historical movement described by Jean Fourastié, which led to the gradual introduction of the double-entry system at the end of the Middle Ages in Italy, in fact also led to the development of modern credit money, and finally to capitalism itself. But in order to demonstrate this, we must follow the three great stages, the three technical evolutions, simple enough in themselves, which led to the development of the double coin. First, the invention of the T-shaped client account, with a debit and a credit, then the inversion of the cash sign, and finally the invention, or at least the rigorous and modern definition, of the notion of profit. These three elements, which took almost two centuries to be applied together, define what we call double-entry bookkeeping, and are still the basis of most modern bookkeeping around the world. When applied, they provided an automated and secure method of managing credit by linking it to money and profit. The nature of the links between money, goods, claims and profit was in fact rigorously and automatically defined in this technique, and the banks that used it were able to manage credit more efficiently than any other, since they automatically linked its expansion to that of profit. By becoming widespread, the method thus led to an unprecedented expansion of credit, and to an unprecedented stimulation of the profit to which it was thus attached. This was the birth of modern credit money. But before coming to this conclusion, we must return to the initial situation of the Middle Ages the shortage of credit due to the Church's ban on interest-bearing loans. It was in response to this shortage that the amazing logic of double-entry bookkeeping developed.

\section{Stimulating Receivables Management Techniques}

The initial fact is this: we have seen that credit was severely restricted by the Church in the Middle Ages, notably because of the prohibition of explicit interest-bearing loans, although these could eventually continue to exist in a clandestine manner. But this does not prohibit a delay in payment, which can easily include a hidden interest. As we have seen, a payment term is a commodity given in exchange for a promise to pay. Every promise of payment is a value, a potential currency if it starts to circulate. The term of payment is therefore a specific form of credit, and the situation in the Middle Ages created a very strong incentive to use it. Historians show us that this tool was used on a daily basis by all actors, whether the promise of payment given in exchange for the payment period was oral or written, but in any case there was strong pressure to use them, and therefore also to develop their administrative management techniques. This was particularly true for private companies, of course, i.e., merchants. It was they who had the greatest interest in using payment terms, since they were the ones who, because of the scale of their activities, needed credit the most to develop. In this context, the payment term was a way for the merchant to expand, to stretch the money available over time, as it were. However, due to the nature and scope of their activities, the number of payment terms that merchants had to manage was very large, especially since it was in their interest to do so. The problem arose of the administrative management of these payment terms, or more precisely of the promises of payment obtained in exchange for gifts of merchandise, i.e., claims. Indeed, it was no longer possible, as it was for a private individual, to manage "from the head", with the help of a simple memory, the money that one owed to the merchant or that one lent him. The very fact of writing down these debts and receivables in a book, as the merchant certainly did at first, had reached its limits. Moreover, this method of spontaneous chronological notation, which everyone can use easily, does not facilitate the exchange of debts. If A owes money to the merchant, and B owes money to A, he can ask the merchant to transfer his debt to B. If the merchant accepts, he circulates a claim, that is, he monetizes it, even in an embryonic way. He ceases to be in the context of a bilateral claim, and becomes an intermediary circulating a claim between A and B. He begins to play the role of a bank, even if he is himself a merchant. As Jean Fourastié has shown, it was this situation, this pressure to improve techniques for managing payment periods, that led the Italian merchants of the Middle Ages to invent the first essential element of double-entry bookkeeping: the T-account, in other words, the third-party account, the debt and receivable account, dare e havere in Italian, doit et avoir in French, débit and crédit.

\section{The Invention of T-Accounts}

The T-account with a debit and a credit is the first fundamental element that forms the basis of the modern accounting method. It is a third party account, in other words a client account, which shows a debit column with the amount that the client owes to the company that keeps the accounts, and a credit column, to note what the company owes him. This extremely simple system is at the same time a fundamental step, because it marks the appearance of the double-entry bookkeeping mechanism. In fact, if you keep several accounts for each customer with whom you have or have given promises of payment, it is necessary to use this mechanism to transfer debts from one account to another. Let's take the following example: 


\begin{tabular}{|c|c|c|c|c|}
\hline & \multicolumn{2}{|c|}{ Customer X } & \multicolumn{2}{|c|}{ Customer Y } \\
\hline & Debit & Credit & Debit & Credit \\
\hline $\begin{array}{l}\text { Initial situation } \\
\text { Transfer of a claim from } X \text { to } \\
Y\end{array}$ & 50 & 50 & $\begin{array}{l}100 \\
50\end{array}$ & \\
\hline Balance & 0 & & 150 & \\
\hline
\end{tabular}

In this case, we see that in the original situation, $X$ owed 50 and $Y$ owed 100 to the merchant. In other words, they both make a promise to pay him. But $\mathrm{X}$ asks to transfer his debt to $\mathrm{Y}$ (because $\mathrm{Y}$ owes him money), so this transaction is taken care of by a credit in X's account and a debit of the same amount in X's account. This transaction leads to a new balance that can easily be calculated for each account. The fact that an entry is made both to the credit of X's account and to the debit of Y's account for the same amount is the intangible and permanent rule of double-entry accounting. It will be generalized, as we shall see, to all the economic movements of a company and a bank, but its birth as such, as a simple golden rule, appears at the time of the invention of T-accounts.

This invention seems like nothing, so simple in conception, but it must be seen that it has not always existed in history. According to Fourastié, the first account of this kind to have been found in the archives dates only from 1211 in Florence, whereas the invention of accounting itself is much older, and has had a very long history up to that date, since it probably dates from the invention of writing. In fact, archaeologists even agree that the first Sumerian tablets that generally mark the beginnings of writing are in fact accounting inscriptions, whose deep links with the circulation of the first ancient credit currencies have been well demonstrated by David Graeber. The accounts of T-shaped correspondents, as obvious as they seem to us since our civilization uses them constantly, are therefore not obvious a priori. In reality, they are already a tool, and an advanced and very efficient one, of modern credit. Indeed, their extremely simple and intuitive use, thanks to the double entry rule, allows the management of a considerable quantity of receivables with a very important number of customers. Because, however intertwined the credit relations between the company that manages this accounting and the other clients, and between the clients themselves, it is possible to keep up to date without difficulty, on a daily basis, the balance of what each client owes. This T-account system, with its associated double-entry bookkeeping system, is therefore a simple but already highly effective invention for credit management. Basically, it is a tool for the circulation of credit between different clients, and this is why it is, par excellence, a tool for the transformation of claims into money. Indeed, thanks to this innovation, credit ceases to be a bilateral act in which it remains a simple credit, or a simple claim. It acquires here a quality of circulation between agents that is the necessary step for its transformation into money, and this is what happened when merchants used this method. With the double part, they began to circulate their claims and thus transformed them into money, themselves becoming bankers. But this money, born from the circulation of their claims, was a new money, not having exactly the same quality as real money. It is little by little that it will acquire these properties, under the action of the States which will want to use it and to secure it, to protect themselves from the financial crises which destroyed it periodically, by creating the public banks which will prefigure the modern central banks. But when this task was fully accomplished in the 19th and 20th centuries, the old initial currency suddenly appeared for what it had been for a long time, an obsolete legacy of the past, and it was finished with the end of the gold standard.

This invention of the T-account came about in the Middle Ages, as we have seen, precisely because there was strong economic pressure to improve the management of these promises of payment, in the form of payment terms (i.e., a promise of payment given in exchange for goods). The Church's prohibition of interest-bearing loans created this situation, which is why this invention certainly originated in Italy in the Middle Ages. However, research has been carried out, without really succeeding, to find out if this origin was not more distant, and in particular from the Arab civilization, very advanced at that time in the management of credit, and whose commercial links with Italy were very numerous. This would not be illogical when one knows that Islam also prohibited interest-bearing loans, and therefore sought devious ways to use credit, just like modern "Islamic finance". In the absence of any document attesting to this, it is better for the moment to favor the thesis of Italian invention, even if it is clear that the links with Arab merchants could only have stimulated innovations in this field at that time. Moreover, we know that the credit systems of the Islamic world were extremely developed at that time, and largely prepared the economic blossoming of the Mediterranean world. David Graeber has also brilliantly shown in his works that the merchants of the Muslim world, as well as the 
Mesopotamian merchants who invented writing in the Fourth Millennium B.C., did use forms of credit money, even if, as we shall see, these currencies did not possess that connection to the rational calculation of profit which made the technical superiority of credit money born in Italy. It is also clear that the adoption of Arabic numerals was an important point for the proper functioning of the double entry and T-accounts.

In any case, this innovation had a major impact on the development of credit, in the form of the payment term. But this development of promises to pay was the work of commercial enterprises, of merchants, since they were the ones who had developed it. This was the beginning of the classic Renaissance figure known as the merchant-banker. By starting from a commercial enterprise, by developing accounting techniques, the merchant found himself de facto in the position of banker. Indeed, if we start again with our example, we immediately see that the merchant's act, with the promises of payment that he initially contracted for his commercial activity, is in fact a banking intermediation activity. By transferring promises of payment from one correspondent to another, he circulates credit, that is, let us not forget that he tends to transform promises of payment into money. Of course, this operation is usual and does not cause any change as long as it is marginal, as it must have been until the invention of the T-account. But when it appears, it constitutes an obvious comparative advantage for the merchant who uses it, as history shows us many examples. It allows for a change of scale in the management of debts, and to do so in a massive way while always keeping the same accuracy. It therefore tends to direct the promises of payment to the one who masters this technique, and transforms him into a banker.

It is clear that it was the invention of the T-account, at least at the beginning of the $13^{\text {th }}$ century, that allowed the first development of credit, of the bills of exchange that materialize it, and of the merchant-bankers who manage it. The historical chronology for this innovation, as for the other stages in the development of modern accounting, follows the movement perfectly. During this period, and especially in Genoa, many banks developed credit in large proportions thanks to this system, including public banks (such as the Casa di San Giorgio).

But if the promises of payment are much better managed with this system, they remain a system in itself, independent, in a way, of the management of the cash flow of the company that follows them and finally similar to the forms of credit currencies of the past. Thus, at the moment of the final payment of a debt by a correspondent to the company keeping the accounts, the double-entry rule no longer applied, since real money was returned to the cash register. The credit entry that was then logically used for the correspondent's account could no longer correspond to a debit, since it was indeed money that was being returned to the treasurer's cashier's office, and the use of the term "debit" would therefore have been absurd. Therefore, the treasury book was kept separately, as we shall see. However, it is obvious that all the receivables of a company must be related to its cash flow. For a merchant with such an accounting system, the problem is this: he wants to make money and has developed a technique of managing receivables to use them as much as possible, i.e., to develop his business. But too many receivables, in either direction, put his cash flow at risk, because these promises may not be honored, or he may not be able to honor them. Therefore, it is clearly and vitally important for him to link these receivables to the general economic organization of his company. Now, these receivables, as he ensures an excellent accounting follow-up, tend to develop more than the rest. Of course, some people take advantage of this to devote themselves solely to managing these promises, i.e., to become bankers, but in any case, merchants and bankers alike feel the need to better link all of their accounting, and especially their cash flow, to this T-account system that works so remarkably well for their receivables. The company's money and receivables must be linked in the same filing system. It all comes down to this problem. Such a problem is in fact equivalent to articulating two dimensions of money. It is a question of rigorously defining the links between official money and a currency in gestation. But this is a theoretical question, and the accountants of the time, like their successors, did not ask it in these terms. For them, the only thing that mattered was the practical virtue of their classification system, and they sought above all to better link their cash flow to their commitments, in order to be able to find their way around in current management. It is this necessity that will lead to the second decisive step in the construction of modern double-entry accounting: the inversion of the cash sign.

\section{The Inversion of the Sign of the Case}

In his books published during the war for the use of students at the Ecole Libre des Sciences Politiques (which later became the Institut d'Etudes Politiques), the result of years of research on the subject, Jean Fourastié clearly showed the essential role that the inversion of the cash sign played in the invention of modern accounting. First, as we shall see, this role was the unification of the company's cash with its receivables. In the end, this meant defining in the same logical framework the two dimensions of money: real money and money in the making, i.e., claims in circulation between customers. From this point of view, double-entry bookkeeping thus became the privileged tool for passing from one currency to another, and this is why its application led to the emergence of modern credit money with the development of bills of exchange. This property, however, remained largely unconscious throughout history, just as the existence of 
two dimensions of money, or if one prefers two levels, two forms of money, or at least two currencies, remained unconscious. But on the other hand, and this point is also of great importance, this innovation marked the break of accounting logic with common sense, with the apparent meaning of the words "debit" and "credit", which were used from then on in a purely conventional way, but whose use remained like a trap for anyone who approached the accounting documents of the double entry without being aware of its singular logic. It is therefore necessary to return in detail to the origin of this second fundamental invention, on the road to the construction of modern accounting.

After the invention of T-accounts and the development of credits, in the form of payment terms, these developed widely. But while the golden rule of the double entry - "one credit for one debit of the same amount" - applied in an intangible way to the accounts of the clients with whom these receivables were contracted, especially when it was a question of moving these receivables from one client to another, it ceased to apply at the moment of payment of a receivable. Let's take our example again:

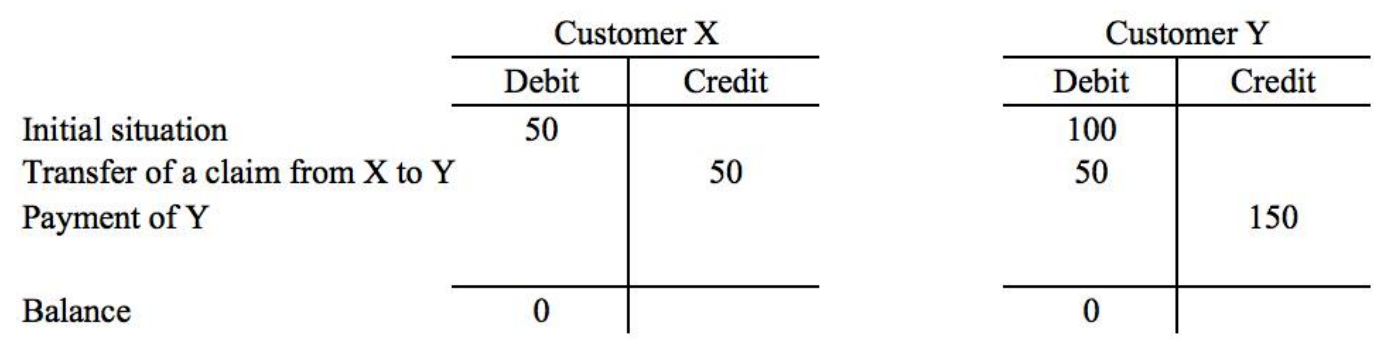

\begin{tabular}{lc|c} 
& \multicolumn{2}{c}{ Cash Account } \\
\cline { 2 - 3 } Payment of Y & Debit & Credit \\
\cline { 2 - 2 } & 150 \\
& \\
Balance & & \\
\hline & & 150
\end{tabular}

We can see the following: while a transfer of a debt from X to Y gives rise to the classic rule: "a credit for a debit of the same amount", which is the basis of the double entry, the payment of this debt gives rise to two credit entries. The accountant credits X's account, to signify that his debt to the company has disappeared, but also credits the cash position, to signify that the latter has increased by the amount paid. It is therefore clear that the cash flow is not included in the golden rule of the double entry, for logical reasons. But this posed a problem for the accountants of the $14^{\text {th }}$ century for the following reason: it was this golden rule of the double entry that had brought about a considerable improvement in the management of the company's debts and receivables. It had allowed the expansion of credit in the companies that used it because it allowed the efficient circulation of credit. It allowed for the automation of the management of receivables, since there was no longer any need to think about the transfer of one of these receivables from one customer to another, no longer any need to worry about the enormous overlapping of situations and transfers, since at any given moment the T-account of each customer allowed for a reliable and rigorous vision of his net position with respect to the company. In other words, the Italian merchants of the $14^{\text {th }}$ century and their accountants were aware of the great efficiency of the invention of the T-account and the golden rule of "one credit for one debit", which had already allowed them to become rich by transforming themselves into bankers. And the fact that their company's cash flow did not fit into this management system posed a problem of the utmost importance to them. They were obliged, as Fourastié showed from the accounting of the firm Bonsignori of Siena, to keep two separate books of account for their clients' accounts and for their cash flow. They could not automate the management of their cash flow as they could the management of their receivables from their customers. And they rightly felt that this state of affairs was an obstacle on the road to an even greater rationalization of their system, a rationalization that could bring them even more benefits than their previous invention had. They wanted to remove this obstacle, they wanted to integrate the treasury into their new system, and to put an end to the duality of their accounting, to unify it in the double-entry system, in the golden rule that made them rich bankers: "one credit for one debit". This was the state of mind that led them to take the decisive step that would change the nature of accounting and bring it into a new era. They had a strong desire to solve the problem they 
faced, and they solved it in the most daring way: by breaking with the meaning of the words "credit" and "debit", and therefore with common sense, by breaking with intuitive, apparent logic, and by giving priority to the practical efficiency of their system, even if it meant leaving its theoretical meaning in the shade for a long time. This is how they decided to invert the sign of the cash register. Henceforth, money entering the cash register would be a debit, and money leaving it a credit, despite the meaning of these words, which became pure conventions until today. Fourastié notes that originally, it was the third-party accounts that certainly had to be reversed to correspond to the cash entries, so that the accounting would make sense for the company. But this posed a serious problem: the customer's lack of understanding when presented with his account sheet where debit and credit were reversed. To avoid this insurmountable problem, it was decided to keep the company's internal accounting in reverse in order to keep an intuitive logic for the customers' accounts. This explains why third-party accounts, or today's customer deposit accounts in banks, retain their usual and intuitive meaning. In fact, all double-entry accounting has been built around this understanding by the customer of his account, until today.

If we take the previous example, we obtain the following entries:

Customer X

\begin{tabular}{lc|c}
\cline { 2 - 3 } & Debit & Credit \\
\cline { 2 - 3 } Initial situation & 50 & \multirow{2}{*}{50} \\
Transfer of a claim from X to $\mathrm{Y}$ & & \\
Payment of $Y$ & & \\
Balance & &
\end{tabular}

Cash Account

Payment of Y

Balance

\begin{tabular}{c|c}
\hline Debit & Credit \\
\hline 150 & \\
& \\
& \\
\hline 150 &
\end{tabular}

\section{Customer Y}

\begin{tabular}{c|c}
\hline Debit & Credit \\
\hline 100 & \\
50 & \\
& 150 \\
\hline 0 & \\
\hline
\end{tabular}

This innovation appeared for the first time in the accounts of the Bonsignori firm of Siena in 1290. If the Italian merchants and accountants of the $13^{\text {th }}$ century are therefore the inventors of this innovation, which is at the heart of the modern double-entry bookkeeping system, it is to Jean Fourastié's great credit that he discovered and described it, and thus gave the keys to understanding what double-entry bookkeeping is. But if he uncovered the logic that led to the inversion of the cash sign, he did not make a more in-depth theoretical analysis. He simply shows that the accounts receivable were kept "in the customer's direction" while the cash was kept "in the firm's direction”, which simply serves to impress upon his students the conventional nature of accounting vocabulary. But if we take a step back, we see that what was at the heart of the problem posed to the accountants of the time was much more than a problem of the meaning of bookkeeping. What was at stake, at the very heart of the accounting of these merchants, was the problem of distinguishing the two dimensions of money, its two forms: money in itself, and debts in circulation. The whole problem consisted in unifying in a simple accounting framework two forms of value that were different in their essence. One, real money, recognized institutionally, was that of cash accounts. The other, money in the making, i.e., claims on third-party accounts, circulated, existed because of this circulation, thanks to the "one credit for one debit" rule. Although the accountants of that time were certainly not sensitive to this theoretical problem, it was nevertheless the problem they were dealing with. Through the search for purely practical efficiency, they were in fact led to draw out general rules of articulation, to define in rigorous, accounting terms, the relations between these two forms of value. This is the reason why the inversion of the sign of the cash led to making the accounting method thus created a very effective tool for passing between these two monetary dimensions. And by allowing this passage, by automating it thanks to the golden rule "one credit for one debit", that is to say by automating the existing relations between the two forms of value (real money and claims), double-entry bookkeeping allowed in fact the expansion of these claims and their progressive transformation into pure and simple money: the modern credit money that we use. How was this expansion facilitated? 
Because credit money, the immaterial money that comes from claims, could not expand beyond a certain point. It was conceptually linked to real money, which limited its expansion in the short run, but favored it in the long run, because its use was rationalized and made economic actors trust it more. Aristotle's ancient concern about the sterility of increasing the money supply, which at that time was intensely discussed and in fact reaffirmed by St. Thomas Aquinas in his Summa Theologica, and then by the scholastic doctors who succeeded him and created the first Universities, was thus circumvented by practice. While Thomas Aquinas, rightly questioned by the great merchants of the time on the question of the nature and justification of profit, had reaffirmed, and perhaps firmly introduced, the prohibition of classical interest lending in the Western market economy, credit found a new way to develop, a way that it would never have taken if classical interest lending had been authorized, and this way was that of developing and circulating debts, i.e., of inventing a new currency. The tool of this new path was double-entry bookkeeping, and the inversion of the cash sign allowed these promises of payment to be firmly linked to real money. Nevertheless, this is especially true because the promises of payment and real money, linked rigorously by the inversion of the cash sign, were themselves linked to the notion of profit, which was the third and last fundamental invention that gave rise to modern double-entry bookkeeping.

\section{The Rational Definition of the Concept of Profit}

No doubt the concept of profit per se already existed before the invention of double-entry bookkeeping, at least as a vague notion of money earned by a business. However, the invention of the profit and loss account gave it its precise, modern definition. By giving the entrepreneur a precise and automated concept, it allowed him to rationally pursue his profit, which remains the intangible goal of every private entrepreneur to this day.

The rigorous and complete definition of profit was thus the work of double-entry accounting. As Fourastié has shown, it resulted from the two previous innovations: the invention of the T-account and the inversion of the cash sign. It was a response to the following problem: integrating the goods accounts into the accounting system of the company. Indeed, the goods owned by a company represent a part, sometimes very important for a merchant, of the value of his assets. But this value is not a monetary value, and it is therefore not taken into account in the company's cash flow, nor in its debts and receivables. In fact, this value is a value that must be estimated by the merchant himself, because a fundamental uncertainty weighs on it. Of course, it is possible to consider that the value of the merchandise is the purchase value, but this purchase value does not necessarily correspond to the sale value. This value can vary because the company has transformed this merchandise through productive work in the case of a craft or industrial company, giving it something more that translates into a higher selling price. But even in the case of a purely commercial enterprise, as many existed in Italy at that time, the sale value can be different from the purchase value because of a variation in the price of the good on the markets. This element, simple to understand once it has been properly isolated, is crucial for understanding the evolution of accounting and capitalism in general. It is the expression of the following fact: the price of goods is fluctuating, in the Middle Ages as today, in fact since the beginning of a free price system. To be more precise, we should say: the price of goods fluctuates over time. In other words, it is impossible to give a definitive, objective value to a good, because this value will depend on a set of incalculable factors and stemming from various determinants that will lead to the only objective reality: the purchase price on a market at time $t$.

When the Italian accountants of the $14^{\text {th }}$ century, sure of the superiority of their new accounting management technique, articulating money and promises of payment with the golden rule of "one credit for one debit", wanted to integrate the accounts of goods into this efficient system, in order to unify in their system the total value of the enterprise, they faced this central theoretical problem. As had been the case since the origins of double-entry bookkeeping a century earlier, they did not position themselves as theoreticians faced with this problem, but as pragmatic practitioners. And a seemingly insurmountable problem presented itself to these practitioners when they wished to integrate goods accounts into the double-entry system: their accounting became absurd. The problem they faced can be represented as follows:

\begin{tabular}{lc|ccc|c} 
& \multicolumn{2}{c}{ Merchandises account } & & \multicolumn{2}{c}{ Cash Account } \\
\cline { 2 - 3 } \cline { 5 - 5 } $\begin{array}{l}\text { Purchase of } \\
\text { merchandise } \\
\text { Sale of merchandise }\end{array}$ & 5000 & & Debit & Credit \\
\cline { 2 - 3 } & & 6000 & & 5000 & 5000 \\
Balance & - & $\underline{1000}$ & $\underline{1000}$ &
\end{tabular}


Firstly, it should be noted that the meaning of the words debit and credit seems to be reversed, whether for the cash account or the commodity account. This is not surprising, because we have just seen that the inversion of the cash sign, that is, the inversion of the meaning of the words debit and credit, was the great reform of double-entry bookkeeping at the beginning of the $14^{\text {th }}$ century. From then on, integrating merchandise accounts into this logic necessarily led to reversing the usual meaning of the words credit and debit for these accounts as well, as we can see here. This was not a problem for the Italian accountants of the $14^{\text {th }}$ century, because they had definitively broken with the meaning of the words "debit" and "credit", which for them were no longer anything more than a convention, except when they concerned accounts of debts and receivables with respect to customers, kept, as we have said, in the sense of these customers in order to be able to present them easily and on request with a statement of what they owed to the firm or what the firm owed them.

But the real problem "for the accountants of the heroic age" in this scheme was the absurd meaning of the commodity account after a purchase and sale. The first thing we see is that this merchandise was purchased for 5,000, so applying the golden rule of double entry, and remembering the reversal of the meaning of the words "debit" and "credit" for the two accounts, we see a debit of 5,000 in the merchandise account, indicating that the company has merchandise of this value, and a credit of 5,000 in the cash account, indicating that this amount was taken out of the treasury. So far, everything seems to conform to the logic of the double-entry system. But the sale of goods is made at a higher price than the purchase, which is the classic case of a company making money. The merchandise is therefore sold for 6000, which results in a debit of this amount from the cash account, indicating that the money has been returned to the cash register, and a credit of 6000 to the merchandise account, also in accordance with the golden rule of the double entry. The cash balance is therefore 1000, since a larger receipt has supplemented an expenditure, but, and this is the problem, the merchandise account balance is absurd, since it indicates that the company has merchandise worth -1000. By integrating the merchandise accounts into the double-entry system, we end up with a merchandise account with a negative value. This rightly appeared to the accountants of the time as absurd, and prevented the generalization of their method for a long time, at least half a century.

As Fourastié has shown, an accountant whose name is unknown, but whose first application can be seen in the accounting of the Massari of Genoa in 1340, took the initiative of creating an account to balance the accounts of goods and transfer all their absurd balances. This catch-all account, whose purpose was to preserve the logic of the doubleentry system by balancing the whole system, would eventually prove to have great economic significance, since it was in fact the profit and loss account. If we go back to the original problem, we obtain the following solution:

\begin{tabular}{|c|c|c|c|c|}
\hline & \multicolumn{2}{|c|}{ Merchandises account } & \multicolumn{2}{|c|}{ Cash account } \\
\hline & Debit & Credit & Debit & Credit \\
\hline $\begin{array}{l}\text { Purchase of } \\
\text { merchandise }\end{array}$ & 5000 & & & 5000 \\
\hline Sale of merchandise & & 6000 & 6000 & \\
\hline $\begin{array}{l}\text { Transfer of the } \\
\text { balance }\end{array}$ & 1000 & & & \\
\hline$\underline{\text { Balance }}$ & $\underline{0}$ & $\underline{0}$ & $\underline{1000}$ & \\
\hline & Profit ar & account & & \\
\hline & Debit & Credit & & \\
\hline $\begin{array}{l}\text { Transfer of the } \\
\text { balance }\end{array}$ & & 1000 & & \\
\hline Balance & & 1000 & & \\
\hline
\end{tabular}


Here, we see that the profit and loss account regains an intuitive meaning, since a credit is a profit and a debit is a loss. With this invention, made by trial and error and in response to practical concerns, double-entry bookkeeping was completed in its essential principles, as Fourastié has shown, and it will not change again until today.

But Fourastié, did not take his analysis of accounting and its consequences any further. While he unraveled the essential problem of the origin, and therefore the logic, of double-entry bookkeeping, an explanation that unfortunately remains too often ignored, he did not seek to follow the historical consequences of such an invention, nor to explore its profound economic significance. As a practitioner himself, like the inventors of this system, he did not attempt to make a detailed analysis of his discovery, and confined himself to its purely practical and functional utility, neglecting, or perhaps underestimating, the very important consequences that it has for the economic and historical analysis of money and capitalism. It is indeed this lack that this thesis seeks to fill, and the question of the invention of the profit and loss account already necessarily requires such an analytical deepening.

For, beyond the pragmatic solution found to the technical problem of 14th-century accountants, it is necessary to understand what this new account represents, which made it possible to "complete" the double-entry system. As with the inversion of the cash sign, what might appear to be a technical problem of the second order was in fact the manifestation of a general and essential economic problem: that of the necessity of taking into account the price system in private accounting. As we have said, the price of a good varies over time, and this is a fundamental and intangible characteristic of economic activity. As authors like Hayek would later discover, this is the very definition of what we call the price system, and this is not only true for our modern economies, but was also true in past economies. This variation in prices makes it impossible to calculate exactly what goods a firm owns at time $t$, and this accounting problem is permanent. For how can a firm's assets be valued in its accounts in any other way than arbitrarily, especially if the price of these assets fluctuates greatly? This is a problem that no one will ever be able to solve, and which is reflected in the current debates on "fair value" in finance, which strangely echoes the problem of the "just price" of the Thomist doctors. At the time of the invention of the double-entry bookkeeping system, it was in fact this problem that underlay the integration of the company's assets into the double-entry bookkeeping system, and which led to the invention of the income statement. And it is in fact always the same problem that we are talking about in finance, since it is indeed the valuation of the company's assets (i.e., let us not forget, what is on the debit side (or on the asset side) of all its accounts), which poses the problem of fair value. Now, these asset accounts owe their presence in a company's balance sheet precisely to the invention of the income statement in the $14^{\text {th }}$ century, which is its counterpart on the liabilities side.

But what the Italian accountants of the medieval period had uncovered with the profit and loss account was much more than a catch-all account for "closing out" their system. What they had created was an account that recorded all the variations in the prices of their goods, between purchase and sale. Depending on whether these changes were favorable or unfavorable to them, the counterpart was an increase or decrease in their cash flow or receivables. So, with this new account, they had managed, without consciously intending to do so, to isolate precisely, to give a rigorous accounting definition, of what the company gained or lost each year. They had thus given a precise definition to an old concept: profit.

It should be noted that this profit, thus defined as the inevitable consequence of price variation, gave rise to lively debates in the thinking of the scholastic doctors of the Church, impregnated with the rediscovery of Aristotle's thought. St. Thomas Aquinas, the most influential of them, while concerned about the usury that such profits could potentially generate, nevertheless recognized their legitimacy. During the $13^{\text {th }}$ century, merchants asked him very clearly whether this type of profit, brought about by the difference in time and place in the purchase and sale of a good, was condemnable as usury or not. Under certain strict conditions, Thomas Aquinas admits that it is not. He defines, in his Summa Theologica, the possibility of trade as a shameful but not condemnable activity, and ends up establishing the fundamental importance of the notion of "just price", which little by little, Thomists as well as scholastics in general will end up defining as the market price. Under these conditions, the way was open for the expansion of modern profit, which was not contradictory to the scholastic doctrine of the Church.

This accounting definition of profit may seem obvious to those of us who are accustomed to this notion, which has since been a total success, both in private economic activity and in the most penetrating economic analyses, such as that of Karl Marx. But we must bear in mind that this precise and rigorous definition of profit, including all the elements of value of the enterprise, whether they are patrimonial, monetary or concern claims, was entirely new in the $14^{\text {th }}$ century. Before the invention of the profit and loss account, or income statement, the notion of profit was incomplete, changing, uncertain, in short, wrong. The profit and loss account, born of a persistent search to unify corporate accounting, was a mathematically precise, exact, verifiable, automatic solution whose effectiveness has hardly been improved since. It 
gave the company that used it a compass to find its way at any moment in the business, it rationalized its organization, it set a fixed goal, which it would not fail to pursue over the centuries. In the literal sense, it gave birth to, or at least brought to a conscious state, capitalism, in the sense that it now had a fixed and precise definition of its raison d'être, even if it only concerned a few bold innovators. This raison-d'être was quite simply the search for profit, that is, the accumulation of capital. Between the invention of the tool that made this rational activity possible and Marx's theoretical awareness of this reality, several centuries were necessary, during which double-entry accounting and its iron logic became more and more important for companies and banks. As de Roover has shown, without however going to the end of the consequences of his analysis, the birth of double-entry bookkeeping is to be situated in 1340, in the bookkeeping of the Massari of Genoa. With the profit and loss account, that is, with the invention of profit in the modern sense, this accounting had now acquired a formidable perfection and efficiency. It had yielded a priceless treasure, which many economists would often look for in vain in history: a precise and complete definition of value.

But before it spread to the logic of all businesses, which was really the case with the expansion of industrial accounting in the $19^{\text {th }}$ century, it was in the field of banking and money that this new technique produced a real revolution, starting at the end of the Middle Ages in Italy.

\section{Double-Entry Accounting: A Rational Definition of Value}

From 1340 onwards, double-entry bookkeeping, as we know it, was born in Northern Italy. The three fundamental innovations that define it, in fact, all appeared in those great Italian commercial cities that were to be the focal points of the Renaissance, and were important commercial centers of the medieval world: the appearance of T-accounts in Florence in 1211, the inversion of the cash sign in 1290 in Siena, and the invention of the profit and loss account in 1340 in Genoa. This general picture, in itself, can only arouse astonishment. For during the century and a half that this technique was developed, and then during the following two centuries that marked its expansion in other Italian cities, among which Florence and Venice would figure prominently, it seems that double-entry bookkeeping closely followed, and even preceded, the emergence of the great intellectual and artistic movement that historians call the Renaissance. This, after all, is hardly surprising. We have seen that the invention of this technique was the work of the great Italian merchants and their accountants, those who were to become the famous merchant-bankers who, through their enrichment and patronage, would produce the intellectual explosion of the Renaissance. In this picture, double-entry bookkeeping, which, as we shall see, would allow the development of commerce and banking, was undoubtedly a gas pedal of the enrichment of these merchant-bankers, and largely propelled the dynamics of nascent capitalism. However, it was the development of trade, from the $11^{\text {th }}$ and $12^{\text {th }}$ centuries in the Italian port cities, and the Church's doctrine on usury, adapted by the teaching of Saint Thomas Aquinas and his successors, which gave free rein to non-usurious trade, that led to the invention of this technique. There was thus a back and forth movement between the renewal of thought, the rise of commerce, and the invention of double-entry bookkeeping, but the latter clearly played a role in the appearance of the renaissance.

Having defined its logic, that is, having made its history, as Jean Fourastié did, and then having deepened its theoretical meaning for each of the three stages that marked its development, we must now define the complete system. After all, what is double-entry bookkeeping, as it was born in 1340 ?

Basically, it is an automated and connected management system of promises to pay, money, and corporate profit. In its essence, it is also and above all a technique for the complete definition of value. It is this characteristic that explains its great fruitfulness when it is used in economic theory, as this thesis seeks to do.

It is a reliable system, allowing permanent verification, on a daily basis, by checking the balance of the double entry, and which greatly reduces the risk of error in accounting entries. It is a simple system to use, which, with the general use of the golden rule "one credit for one debit", allows direct transfers between all types of accounts. It is an automated management system, because the accountant does not have to think about the nature of the relationships between profit, receivables and currency. These relationships have been defined at the outset, when the method was developed, and the links between these three elements are therefore derived from the use of the double-entry method; they no longer have to be thought through before being carried out, as was the case previously. This point is crucial. Because what the double part rigorously fixes is not something new in itself, the merchants of earlier centuries knew about profit, money and claims, they knew well, from experience, that for example a profit generated money and that a promise of payment was easier to make for a rich company. But this reasoning of the links between profit, money and promises of payment had to be redone each time an operation presented itself, without a complete vision of value allowing the merchant to know at each moment the real state of the company's wealth and to judge the appropriateness of a decision. 
Everything had to be done on the spur of the moment, in a changing, inconsistent manner, and above all, in a slow manner. With double-entry accounting, on the other hand, the entrepreneur, and even the accountant himself, is relieved of this constraint of reflection, a bit like a modern statistician who is relieved of the calculation by the computer. Double-entry accounting represents something similar in its operation. It initially defines and automates with a simple writing rule the links between profit, promises to pay and money. The links between these three fundamental elements of a company's assets are considerably accelerated and deepened with the use of double-entry accounting. The more double-entry accounting is used, the more the nature of the links between these three elements emerges and appears as an obvious, mechanical, mathematical fact. And these links are essentially these: enrichment comes from profit, and profit comes from capital gains on the sale of goods. To get rich, one must either increase the value of one's goods through production, or speculate on the sale of goods. On the other hand, and this point is the one that will hold our attention for a long time, receivables are an element of wealth, which can be obtained by forward sales of goods, in other words by payment terms. Not only is their development an element of wealth in itself, because many other merchants consider them as such, but they can also be a means of increasing the profit of the enterprise because they allow the purchase of more goods and the realization of more capital gains on sales. They are a new form of credit, but a completely legal form of credit, operating without any apparent interest-bearing loans. Not only do these claims circulate very easily in double-entry bookkeeping, allowing extremely interlocking transactions throughout the day to be settled in the evening with extreme simplicity, but they are also connected in the same way to the real money on which they are based, and to the profit that finances them. For an Italian merchant of this period, double-entry bookkeeping means realizing that he can circulate large quantities of claims on behalf of his customers, while controlling the proportions between the mass of these promises and the deposits of real money, and remunerating these credits with profits obtained from the sale of goods. Thus he has a method of reasoned credit management, thanks to these claims, whose growth is connected at every moment to the growth of profit. This primacy of receivables is not surprising, for it was to enable their proper management and development that the double-entry system was invented, and it succeeds far beyond all expectations. With its rationality and efficiency, it soon became clear that the companies using it had everything they needed to become banks.

In fact, faced with the shortage of credit, they had to see the demand for credit flowing towards them, and they turned mainly to this activity, hence the sudden emergence, in the 14 th and especially in the $15^{\text {th }}$ century, of these great merchant-bankers from crafts and industry such as Fransesco Datini in Prato or the Medici of Florence, who thus began their prodigious rise.

In reality, what made their method so powerful was that it correctly distinguished and unified in a single logical and automatic system the two dimensions of money, real money and claims, and that it efficiently connected them to the rational calculation of profit. Experience has since shown how difficult it is to distinguish between these two elements, and how difficult it is to understand that this form of credit, the claim, is in fact a potential currency, in gestation, which, if recognized and guaranteed by the State, can be transformed into a new currency. The very inventors of double-entry bookkeeping were not really aware of this theoretical distinction, but practical necessity led them, admittedly by means of a construction contrary to common sense, admittedly by breaking with the meaning of the words, to rigorously define this distinction. And by using these claims, by financing their growth through a clearly identified and defined profit, the first merchant-bankers became the managers of this new type of credit that linked the growth of claims to the growth of profit, and they developed it in unprecedented proportions. Indeed, in the conceptual framework of the double-entry system, developing receivables necessarily meant developing cash flow and profit. This new type of credit was therefore connected to profit from the outset. Increasing this credit, these receivables, therefore meant increasing profit, and this was what made this system powerful in the long term, and ensured its development. For the double part prevented it from becoming anarchic, it required a profit for any increase in credit, in other words, on the macroeconomic level, it linked the increase in credit to the increase in production.

\section{Conclusion}

We shall return to this point in detail in future articles, but for the moment we must insist on this definition: double-entry bookkeeping, born of the prohibition of interest-bearing loans and the need for credit, is a complete definition of value. Its invention, from 1211 to 1340, and its subsequent expansion among Italian merchants, led to the transformation of these merchants into merchant-bankers and made them the managers of a new credit system destined to a prodigious expansion: the system of claims exchanged by bills of exchange in the great European fairs. More broadly, this definition of value gave the bankers who used it a practical superiority that was perceived long afterwards by the economists themselves, who were often engaged in their reflections on the construction of an efficient theory of value. To define 
value in a complete way is, however, what double-entry bookkeeping had already achieved in the $14^{\text {th }}$ century, and this is the profound reason for its power and its incredible lifespan in history.

\section{References}

Andreica, I. (2016). Double Entry Bookkeeping Vs Single Entry Bookkeeping. Bulletin of University of Agricultural Sciences and Veterinary Medicine Cluj-Napoca. Horticulture, 73(2), 282-290.

Beaugrand, H. (2020). Plan comptable des Etablissements de Crédit (édition 2020), sur la base d'un ouvrage d'Antoine Sardi, éditions AFGES, 2020.

Braudel, F. (1989). Le modèle italien, Paris, Arthaud.

Comeau, G. (2008). L'achat et la vente à paiement différé, Saint Thomas d'Aquin : http://docteurangelique.free.fr/ bibliotheque/opuscules/66achatetventeatemps.htm

Fourastié, J. (1943). La Comptabilité, Collection que sais-je ? Presses Universitaires de France.

Fourastié, J. (1944). Comptabilité Générale Conforme Au Plan Comptable Général, Librairie Générale De Droit Et De Jurisprudence, Paris.

Gleeson White, J. (2013). Double Entry, How the Merchants of Venice Created Modern Finance. Allen and Unwin, 2013.

Graeber, D. (2016). Dette : 5000 ans d'histoire, Editions Babel.

Hayek (von), F. (1975). Prix et Production, Agora, Calmann-Lévy.

Heers, J. (2012). La Naissance Du Capitalisme Au Moyen Age, Changeurs, Usuriers Et Grands Financiers, Perrin Éditions.

Hoskin, K.W., Ma, D. and Macve, R.H. (2016). Rational Evolution or Socially Constructed Counter-myth? Crosscultural Perceptions of the Development of Chinese Commercial Accounting up to c. 1850 and its Significance. LSE/ University of Birmingham working paper (earlier version at http://www.lse.ac.uk/economicHistory/ workingPapers/ 2012/WP160.pdf ).

Izoulet, M. (2020). Théorie comptable de la monnaie et de la finance, Paris, EHESS, available at Theses.fr : http:// www.theses.fr/2020EHES0110

Izoulet, M. (2021). The Accounting Nature of Money and Claims. International Journal of Management Research and Economics. 1(2), 10-17. doi: 10.51483/IJMRE.1.2.2021. 10-17.

Izoulet, M. (2021). An Accounting History of Credit Money. RA Journal of Applied Research, 7(7), 2458-2466. https:// doi.org/10.47191/rajar/v7i7.06

Lapeyre H. (1975). L'auvre de Raymond de Roover, Revue d'histoire économique et sociale, 53(2/3).

Marx, K. (2006). Le Capital, Critique de l'Économie Politique, Quadrige Grands Textes, PUF, 2006.

Milza, P. (2013). Histoire de l'Italie des origines à nos jours, Fayard.

Munidewi, I.A.B. (2018). Accounting in Reality (AIR) as a Deterrent of Accounting Practices Commonness, The 9th International Conference Rural Research \& Planning Group, 95-101.

Origo I. (1959). Le marchand de Prato, Fransesco di Marco Datini, Editions Albin Michel, 1959.

Poivret, C. (2013). L'importance de la comptabilité au XIX siècle et au début du XX siècle en France ou " la prédominance du chiffre " dans la gestion. XVIIIe Journées d'Histoire de la Comptabilité et du Management, La Rochelle France. Online : https://hal-upec-upem.archives-ouvertes.fr/hal-01256425/document

Roover (de), R. (1937). Aux origines d'une technique intellectuelle : la formation et l'expansion de la comptabilité à partie double. Annales d'histoire économique et sociale.

Roover (de), R. (1956). L'évolution de la lettre de change, XIV - XVIII siècle, 1956, Affaires et gens d'affaires, éditions Armand Collin.

Roover (de), R. (1958). The Concept of the Just Price: Theory and Economic Policy, The Journal of Economic History, $18(4), 418-434$.

Roover (de), R. (1971). La Pensée Économique des Scolastiques : Doctrines et Méthodes. Montréal : Institut d'Études Médiévales. 
Roover (de), R. (1999). The Rise and Decline of the Medici Bank, 1397-1494, Beard Books.

Saint Thomas d'Aquin (2004). Somme théologique Iia Ilaepars, Question LXXVII, article 4. http://docteurangelique.free.fr/ bibliotheque/sommes/3sommetheologique2a2ae.htm

Sangster, A. (2015). The genesis of double entry bookkeeping. The Accounting Review, http://dx.doi.org/10.2308/ accr51115 (in press).

Sivéry, G. (2004). La notion économique de l'usure selon saint Thomas d'Aquin. Revue du Nord, 356 - 357, (3), $697-708$. Doi :10.3917/rdn.356.0697.

Soll J. (2015). The Reckoning, Financial Accountability and the Making and Breaking of Nations, Penguin Books.

Van Roey E. (2004). La monnaie d'après saint Thomas d'Aquin. Sa nature, ses fonctions, sa productivité dans les contrats qui s’y rapportent. In : Revue néo-scolastique. 12I’ année, n45, 1905. pp. 27-54.

Vlaeminck, J. H. (1979). Histoire et doctrine de la comptabilité, éditions Pragnos.

Wang, Jing., Zhao, L. and Hooper, Keith, (2017). Is emergence sufficient to explain the origins of Double Entry? Faculty of Business - Papers (Archive). 1732. https://ro.uow.edu.au/buspapers/1732

Warsono, S. (2015). The Rationality of Rules of Debit and Credit. Available at SSRN: https://ssrn.com/abstract=2699053 or https://dx.doi.org/10.2139/ssrn.2699053, http://dx.doi.org/10.2139/ssrn.2699053

Cite this articleas: Maximelzoulet (2021). The Invention of Double-Entry Bookkeeping. I nternational J ournal of M anagement R esearch and E conomics. 1(4), 48-60. doi: 10.51483/ IJ M RE.1.4.2021.48-60. 